19 Revue d'histoire du XIXe siècle

Société d'histoire de la révolution de 1848 et des

révolutions du XIXe siècle

$11 \mid 1995$

L'exil

\title{
Les quarante-huitards roumains en exil
}

\section{Dan Berindei}

\section{OpenEdition}

\section{Journals}

\section{Electronic version}

URL: http://journals.openedition.org/rh19/83

DOI: $10.4000 /$ rh 19.83

ISSN: $1777-5329$

\section{Publisher}

La Société de 1848

\section{Printed version}

Date of publication: 1 June 1995

ISSN: 1265-1354

\section{Electronic reference}

Dan Berindei, «Les quarante-huitards roumains en exil ", Revue d'histoire du XIXe siècle [Online],

11 | 1995, Online since 09 September 2008, connection on 19 April 2019. URL : http:// journals.openedition.org/rh19/83 ; DOI : 10.4000/rh19.83

This text was automatically generated on 19 April 2019

Tous droits réservés 


\section{Les quarante-huitards roumains en exil}

\section{Dan Berindei}

\section{ABSTRACTS}

The Romanian Forty-Eighters in exile The crushing of the Romanian revolution by the Russian and Ottoman military campaigns in fall 1848 caused revolutionaries throughout Europe, and even in Asia Minor to retreat into exile. But the homeland of the exiles remained without question France, although the Empire had dashed all republican hopes. Some Romanian revolutionaries were actively involved in resistance against Louis-Napoléon Bonaparte. For example, Jean C. Bratianu was involved in the "Hippodrome" plot. Romanian exiles, like all refugees, experienced financial hardships and divisions. But it was the home situation, and especially the Crimean War, that caused the revolutionaries to modify their policy, and move towards a dialogue with the Western governments. After an absence of ten years, most of them made a triumphant return and their struggles marked a major episode in the foundation of the Romanian nation.

La répression, à l'automne 1848 , de la révolution roumaine écrasée par les interventions militaires extérieures russes et ottomanes a conduit les révolutionnaires à l'exil dans toute l'Europe et même en Asie Mineure. Mais la patrie des exilés reste bien entendu la France, même si l'Empire met fin aux espérances républicaines. Certains révolutionnaires roumains participent d'ailleurs à la résistance intérieure comme Jean C. Bratianu, un des membres du complot de l'Hippodrome. La proscription roumaine connaît comme d'autres les divisions et les difficultés financières. Mais c'est surtout la situation extérieure, et notamment la guerre de Crimée, qui infléchit la politique des révolutionnaires vers un dialogue avec les gouvernements occidentaux. Au terme de dix années d'absence, la plupart d'entre eux font un retour triomphal et marquent, par leurs luttes, un épisode majeur de fondation de la nation roumaine. 
INDEX

Mots-clés: Roumanie, Exil, Quarante-huitards 